\title{
PENGARUH PEMUPUKAN ANORGANIK DAN ORGANIK TERHADAP PRODUKSI TANAMAN JAGUNG SEBAGAI SUMBER PAKAN.
}

\author{
Frobel G. Dewanto *), J.J.M.R. Londok **), R.A.V. Tuturoong **) \\ dan W. B. Kaunang **) \\ Fakultas Peternakan Universitas Sam Ratulangi Manado, 95115. \\ e-mail : frobel_dewanto@yahoo.com
}

\begin{abstract}
ABSTRAK
Suatu penelitian telah dilakukan untuk melihat sejauh mana pengaruh pemupukan anorganik dan organik terhadap tinggi tanaman, panjang dan lingkar tongkol serta bobot pipilan kering jemur jagung. Penelitian ini dilaksanakan di lahan pertanian milik keluarga $M$. Manoppo yang dimulai sejak bulan April 2009 sampai dengan Oktober 2009 di Desa Koka Kecamatan Tombulu Kabupaten Minahasa. Jumlah petak yang digunakan dalam penelitian ini sebanyak 20 (dua puluh) petak yang ditempatkan secara acak dengan ukuran 2 x 2 meter dengan jarak tanam $50 \mathrm{~cm} \times 70 \mathrm{~cm}$ dan jenis benih jagung yang digunakan adalah jagung hibrida (NUSANTARA 1). Rancangan penelitian yang digunakan adalah Rancangan Acak Kelompok (RAK), terdiri dari 5 kelompok dan 4 perlakuan yang terdiri dari $\mathrm{T}_{0}$ (tanpa pemupukan), $\mathrm{T}_{1}$ (pemupukan anorganik dengan dosis 3,67 $\mathrm{kg} /$ petak), $\mathrm{T}_{2}$ (pemupukan organik dengan dosis $1,4 \quad \mathrm{~kg} /$ petak) dan $\mathrm{T}_{3}$ (menggabungkan pupuk anorganik dengan dosis $1,83 \mathrm{~kg} /$ petak dan pupuk organik dosis $0,7 \mathrm{~kg} /$ petak). Variabel yang diukur meliputi tinggi tanaman, panjang dan lingkar tongkol serta bobot pipilan kering jemur. Pengambilan data dilakukan disaat panen sampai dengan selesai penjemuran jagung yang telah dipipil. Data yang diambil kemudian ditabulasi dan diuji menurut analisis keragaman untuk melihat pengaruh perlakuan. Uji lanjut Beda Nyata Jujur (BNJ) dilakukan
\end{abstract}

\footnotetext{
* Alumni Fakultas Peternakan

*** Jurusan Nutrisi dan Makanan Ternak
}

untuk melihat perbedaan antara masingmasing perlakuan. Hasil analisis keragaman menunjukkan bahwa perlakuan memberi pengaruh yang berbeda nyata $(\mathrm{P}>0,05)$ terhadap panjang dan lingkar tongkol serta bobot pipilan kering jemur. Dari penelitian yang telah dilakukan diambil kesimpulan bahwa pemupukan dengan menggabungkan antara pupuk anorganik dan organik lebih meningkatkan produksi tanaman jagung baik itu panjang tongkol, lingkar tongkol dan bobot pipilan kering jemur.

\section{Kata Kunci: Pupuk anorganik, Pupuk organik dan Produksi tanaman jagung}

\section{ABSTRACT}

EFFECT OF INORGANIC AND ORGANIC FERTILIZER PRODUCTION OF CORN AS A SOURCE OF FORAGE CROPS. A study was conducted to see the influence of inorganic and organic fertilization on plant height, cob length, and girth, and weight of the grain corn. The research was conducted in a family owned farm $\mathrm{M}$. Manoppo wich began in April to Ocbober 2009 in the village of Koka District Tombulu Minahasa Regency. The number of plots used in this study as many as 20 plots randomly placed with a size of $2 \times 2$ sguare meters with a spacing of $50 \times 70$ $\mathrm{cm}$ and the type of seed corn used is corn hybrid (Nusantara 1). The design of the study ia a randomized block design (RGD), consisting of 5 and 4 treatment groups consisting of $\mathrm{T}_{0}$ (without fertilization), $\mathrm{T}_{1}$ (inorganic fertilizer at dose of $3,67 \mathrm{~kg} / \mathrm{plot}$ ), $\mathrm{T}_{2}$ (organic fertilizer with doses of $1,4 \mathrm{~kg} / \mathrm{plot}$ ) and $\mathrm{T}_{3}$ (combining 
inorganic fertilizers with a doses of 1,83 $\mathrm{kg} /$ dose of organic fertilizer plots and 0,7 $\mathrm{kg} / \mathrm{plot}$ ). The variables measured included plant height, cob length and girth, and weight of grain drying. Data is collected when the harvest of up to finish drying the corn that has been grain. Data are taken then tabulated and tested according to the analysis of diversity to see the effect of treatment. Unlike the Tukey's Test is performed to see the differences between each treatment. The analysis show that the treatment given the diversity of influences significantly different $\mathrm{P}>0.05$ on the lenght and girth and weight gran dry cobs. Of research has been done be concluded that fertilization by combining in organic and inorganic fertilizer to increase production of corn cobs either lenght-girth and weight dry cobs.

\section{Keywords: Fertilizer inorganic, Fertilizer organic and Production of corn.}

\section{PENDAHULUAN}

Jagung merupakan bagian dari sub sektor tanaman pangan yang memberikan andil bagi pertumbuhan industri hulu dan pendorong industri hilir yang kontribusinya pada pertumbuhan ekonomi nasional cukup besar. Tanaman jagung juga merupakan salah satu komoditi strategis dan bernilai ekonomis serta mempunyai peluang untuk dikembangkan karena kedudukannya sebagai sumber utama karbohidrat dan protein setelah beras (Anonim, 2003).

Di beberapa daerah di Indonesia, jagung dijadikan sebagai bahan pangan utama juga sebagai sumber bahan pakan ternak dan memiliki andil terbesar dibandingkan dengan bahan lain. Ternak ruminansia mengkonsumsi semua komposisi tanaman jagung yang dipakai sebagai pakan ternak. Peningkatan kebutuhan jagung dalam beberapa tahun terakhir ini tidak sejalan dengan peningkatan produksi dalam negeri.

Peningkatan produksi jagung menunjukkan bahwa produksi jagung nasional rata-rata negatif dan cenderung menurun, sedangkan laju pertumbuhan penduduk selalu positif yang berarti kebutuhan terus meningkat. Pada kenyataannya total produksi dan kebutuhan nasional dari tahun ke tahun menunjukkan kesenjangan yang terus melebar dan jika terus dibiarkan, konsekuensinya adalah peningkatan jumlah impor jagung yang semakin besar dan negara kita semakin tergantung pada negara asing.

Fluktuasi harga bahan pakan dan persaingan dalam penggunaannya merupakan kendala yang sering mengguncang usaha peternakan karena berdampak pada biaya ransum. Dengan adanya krisis ekomomi yang dialami oleh negara kita sampai sekarang, dampak ini juga dirasakan oleh para petani sehingga daya beli masyarakat tani menjadi berkurang dan ditambahkan lagi harga pupuk dan sarana produksi lain yang semakin tinggi.

Fenomena dampak negatif intensifikasi pertanian terhadap ekosistem pertanian terjadi karena intensitas pemakaian pupuk kimia yang terus meningkat dari waktu ke waktu. Pupuk anorganik lebih mudah didapatkan tetapi harganya relatif mahal. Penggunaan pupuk anorganik selalu diikuti dengan masalah lingkungan, baik terhadap kesuburan biologis maupun kondisi fisik tanah serta dampak pada konsumen.Sebagian besar lahan penanaman jagung di Indonesia berupa lahan kering. Masalah 
utama penanaman jagung di lahan kering adalah kebutuhan air sepenuhnya tergantung pada curah hujan, bervariasinya kesuburan lahan dan adanya erosi yang mengakibatkan penurunan kesuburan lahan (Adisarwanto, 2002). Selain itu masalah lain di lahan kering adalah memiliki $\mathrm{pH}$ dan kandungan bahan organik yang rendah.

Di pasaran terdapat dua jenis pupuk yaitu pupuk anorganik dan organik. Pupuk anorganik adalah pupuk hasil proses rekayasa secara kimia, fisik dan atau biologis dan merupakan hasil industri atau pabrik pembuat pupuk. Sedangkan pupuk organik adalah pupuk yang sebagian besar atau seluruhnya terdiri dari bahan organik yang berasal dari tanaman dan atau hewan yang telah melalui proses rekayasa, dapat dibentuk padat atau cair yang digunakan untuk mensuplai bahan organik, memperbaiki sifat fisik, kimia dan biologi tanah.

Pemberian pupuk organik dapat memperbaiki struktur tanah, menaikan bahan serap tanah terhadap air, menaikan kondisi kehidupan di dalam tanah, dan sebagai sumber zat makanan bagi tanaman. Sedangkan pemberian pupuk anorganik dapat merangsang pertumbuhan secara keseluruhan khususnya cabang, batang, daun, dan berperan penting dalam pembentukan hijau daun (Lingga, 2008). Pemupukan bertujuan mengganti unsur hara yang hilang dan menambah persediaan unsur hara yang dibutuhkan tanaman untuk meningkatkan produksi dan mutu tanaman. Ketersediaan unsur hara yang lengkap dan berimbang yang dapat diserap oleh tanaman merupakan faktor yang menentukan pertumbuhan dan produksi tanaman (Nyanjang,2003).

Penelitian ini dilakukan dengan tujuan untuk mengetahui pengaruh pemupukan anorganik dan organik terhadap produksi tanaman jagung. Dengan hipotesis bahwa pemupukan anorganik dan organik memberikan pengaruh terhadap tinggi tanaman, panjang dan lingkar tongkol serta bobot pipilan kering jemur jagung.

\section{MATERI DAN METODE PENELITIAN}

Penelitian ini dilakukan di Kabupaten Minahasa Kec. Tombulu Desa Koka di lahan pertanian milik keluarga M. Manoppo yang dilaksanakan dari bulan April sampai dengan Oktober 2009.

Bahan yang digunakan dalam penelitian ini adalah benih jagung hibrida Nusantara 1, feces ayam (bahan pembuat kompos), jerami jagung, $\quad \mathrm{EM}_{4} \quad$ (effective microorganism), gula aren dan pupuk anorganik (Urea, SP36 dan $\mathrm{KCl}$ ). Sedangkan alat yang digunakan antara lain cangkul, sprayer, gelas ukur, thermometer, moisture meter, $\mathrm{pH}$ meter, timbangan, meteran, alat tulis menulis dan alat dokumentasi.

Penelitian ini menggunakan metode Rancangan Acak Kelompok (RAK) terdiri dari 4 perlakuan dan 5 ulangan (Steel dan Torrie, 1994). Perlakuan disusun sebagai berikut :

$\mathrm{T}_{0}=$ Tanpa pemupukan dengan dosis $0 \mathrm{~kg} /$ petak

$\mathrm{T}_{1}=$ Pemupukkan anorganik dengan dosis $3,67 \mathrm{~kg} /$ petak

$\mathrm{T}_{2}=$ Pemupukkan organik dengan dosis $1,4 \mathrm{~kg} /$ petak 
$\mathrm{T}_{3}=$ Penggabungan kedua jenis pupuk (anorganik dan organik) dengan dosis anorganik 1,83 $\mathrm{kg} /$ petak dan organik 0,7 $\mathrm{kg} /$ petak.

Banyaknya plot/petak percobaan 20 (dua puluh).

1. Persiapan

a. Lahan

Pengolahan lahan diawali dengan membersihkan lahan dari sisa-sisa tanaman sebelumnya. Sisa tanaman yang sudah kering dibakar, abunya dikembalikan ke tanah, kemudian dilanjutkan pencangkulan dengan cara membalik tanah dan memecah bongkah tanah agar diperoleh tanah yang gembur untuk memperbaiki aerasi. Selanjutnya dilakukan pembuatan petakpenanaman sebanyak 20 (dua puluh) petak yang ditempatkan secara acak dengan ukuran 2 x 2 meter.

b. Pembuatan Pupuk Organik (Kompos) (Situs resmi Dinas Peternakan Prov. Sumbar, 2008) :

- Jerami jagung dicacah $\pm 3-4 \mathrm{~cm}$.

- Jerami jagung dan feces ayam dicampur lalu diaduk hingga merata dengan perbandingan 1:1.

- Pembuatan larutan starter $(0,1 \%)$; air (1 ltr) ditambah gula aren $(1 \mathrm{gr})$ ditambah $\mathrm{EM}_{4}(1 \mathrm{cc})$ diaduk hinga tercampur dengan rata.

- Larutan starter disemprotkan dengan menggunakan sprayer pada jerami jagung yang sudah bercampur dengan feces.

- Setelah semua campuran merata dimasukkan ke dalam bak penampungan dan ditutup dengan karung goni untuk mempertahankan kondisi anaerob. Bila kondisi anaerob tidak dipertahankan, maka suhu akan naik pada minggu I (pertama) sehingga secara teratur suhu perlu diukur dengan thermometer. Jika suhu mencapai $60^{\circ} \mathrm{C}$ maka perlu dilakukan pembalikkan dan campuran tersebut dianginanginkan selama 5 menit kemudian ditumpuk kembali dan ditutup. Hal ini dilakukan secara berulang-ulang sampai suhu stabil $\left(35^{0}-45^{0} \quad \mathrm{C}\right)$. Pengadukkan pertama dilakukan setelah dua minggu.

- Pengadukan/pembalikkan tumpukkan kompos dilakukan seminggu sekali sampai kompos tersebut siap digunakan (8 minggu) dengan ciri-ciri kompos yang sudah matang adalah terjadinya perubahan warna menjadi coklat kehitaman, tekstur menjadi lunak dan tidak berbau menyengat. Apabila masih basah dapat dikeringkan dengan cara diangin-anginkan supaya mendapatkan hasil yang berkualitas.

- Sebelum digunakan kompos diayak agar supaya bahan dasar pembuatan kompos yang belum terurai dapat dipisahkan.

- Hasil analisa kompos yang digunakan dalam penelitian ini adalah $\mathrm{N} \mathrm{0,282} \mathrm{\% ,} \mathrm{P} \mathrm{25,87} \mathrm{ppm}$ dan K2O 60,06 ppm. (Hasil Analisa di Laboratorium FAPERTA UNSRAT. Manado. 2009). 
Tabel 1. Kandungan Usur Hara Makro Tanah Sebelum Penanaman

\begin{tabular}{cccccc}
\hline Unsur Hara & \multicolumn{5}{c}{ Kelompok } \\
\cline { 2 - 6 } Makro & $\mathbf{A}$ & $\mathbf{B}$ & $\mathbf{C}$ & $\mathbf{D}$ & $\mathbf{E}$ \\
\hline $\mathrm{N}(\%)$ & 0,067 & 0,069 & 0,075 & 0,050 & 0,80 \\
$\mathrm{P}(\mathrm{ppm})$ & 14,40 & 14,20 & 13,99 & 11,04 & 9,66 \\
$\mathrm{~K}(\mathrm{ppm})$ & 8,28 & 7,39 & 6,30 & 3,86 & 6,12 \\
\hline Sumber: Hasil Analisa Tanah di Laboratorium FAPERTA UNSRAT,Manado (2009).
\end{tabular}

2. Penanaman jagung dilakukan dengan jarak tanam $50 \mathrm{~cm} \times 70$ $\mathrm{cm}$, setiap plot/petak memiliki 24 lubang dan setiap lubang ditanami 2 butir jagung. Untuk pemupukan pada perlakuan $\mathrm{T}_{1}$, dilakukan sesuai dengan kebutuhan tanaman jagung yaitu; Urea $300 \mathrm{~kg} / \mathrm{ha}$, SP36 $150 \mathrm{~kg} / \mathrm{ha}, \mathrm{KCl} 75 \mathrm{~kg} / \mathrm{ha}$. Pemberian Urea diberikan sebanyak 2 kali, dimana setengah bagian (dosis pemupukan 0,10 $\mathrm{kg} /$ petak) diberikan saat umur tanam 18 hari dan setengahnya lagi saat umur tanam 35 hari. SP36 dan $\mathrm{KCl}$ diberikan seluruhnya pada saat tanam. Untuk $\mathrm{T}_{2}$, setiap lubang yang belum ditanami jagung diberikan kompos sebanyak $0,02 \mathrm{~kg}$ per lubang, kemudian ditanami jagung. Diaplikasikan pada saat tanam. Untuk $\mathrm{T}_{3}$, pemupukan dilakukan dengan menggabungkan antara jenis pupuk anorganik dan organik dengan perbandingan dosis pupuk anorganik $1,83 \mathrm{~kg} /$ petak dan pupuk organik $0,7 \mathrm{~kg} /$ petak.

Variabel penelitian yang diukur meliputi; 1). Tinggi tanaman $(\mathrm{cm})$. Diukur dari permukaan tanah sampai buku dasar malai, dilakukan pada saat panen. 2). Panjang dan lingkar tongkol (cm). Kulit tongkol dibuka terlebih dahulu dan diukur panjangnya dari pangkal hingga ujung tongkol. Pengukuran dilakukan setelah panen dan 3). Bobot pipilan kering jemur, yaitu setelah panen tongkol jagung yang telah dibuka kulitnya langsung dijemur selama 3 hari kemudian dipipil dan dijemur \pm 2 hari atau kadar air biji setelah mencapai $12-14 \%$ (kg. petak $^{-1}$ ).

\section{HASIL DAN PEMBAHASAN}

\section{Pengaruh Perlakuan terhadap Tinggi Tanaman}

Nilai rata-rata tinggi tanaman dalam penelitian ini dapat dilihat pada Tabel 2.

Tabel 2. Rataan Tinggi Tanaman, Panjang dan Lingkar Tongkol Serta Bobot Pipilan Kering Jemur Jagung pada Setiap Perlakuan

\begin{tabular}{|c|c|c|c|c|}
\hline \multirow{2}{*}{ Peubah } & \multicolumn{4}{|c|}{ Perlakuan } \\
\hline & $\mathbf{T}_{\mathbf{0}}$ & $T_{1}$ & $\mathbf{T}_{2}$ & $\mathbf{T}_{3}$ \\
\hline Tinggi Tanaman $(\mathrm{cm})$ & 180,84 & 180,14 & 185,74 & 187,86 \\
\hline Panjang Tongkol(cm) & $13,15^{\mathrm{a}}$ & $14,03^{\mathrm{a}}$ & $14,14^{\mathrm{a}}$ & $15,76^{\mathrm{b}}$ \\
\hline Lingkar Tongkol $(\mathrm{cm})$ & $14,10^{\mathrm{a}}$ & $14,06^{\mathrm{a}}$ & $14,44^{\mathrm{ab}}$ & $15,62^{\mathrm{b}}$ \\
\hline $\begin{array}{l}\text { Bobot Pipilan } \\
\text { Kering Jemur }\left(\mathrm{kg} . p e t a k^{-1}\right)\end{array}$ & $1.288,32^{\mathrm{a}}$ & $1.134,72^{\mathrm{a}}$ & $1.943,41^{\mathrm{b}}$ & $2.372,37^{\mathrm{c}}$ \\
\hline
\end{tabular}

Keterangan : Superskrip berbeda pada baris yang sama menunjukkan perbedaan yang nyata. 
Rataan tinggi tanaman pada Tabel 2 bervariasi antara 180,14 $\mathrm{cm}( \pm$ $22,25)$ sampai $187,86 \mathrm{~cm}( \pm 16,98)$. Dengan rataan tertinggi pada perlakuan $\mathrm{T}_{3}$ sedangkan terendah pada perlakuan $T_{1}$. Hasil analisa keragaman (Lampiran 1) menunjukkan bahwa perlakuan tidak memberikan pengaruh yang nyata $(\mathrm{P}<0,05)$ terhadap tinggi tanaman dengan kata lain pupuk anorganik dan organik tidak mempengaruhi tinggi tanaman.Hal ini disebabkan karena tidak adanya kompetisi antar tanaman terhadap sinar matahari dan penyerapan unsur hara untuk melakukan proses fotosintesis.

Unsur hara Nitrogen yang dikandung dalam pupuk Urea sangat besar kegunaannya bagi tanaman untuk pertumbuhan dan perkembangan, antara lain; membuat daun tanaman lebih hijau segar dan banyak mengandung butir hijau daun (chlorophyl) yang mempunyai peranan sangat panting dalam proses fotosintesa, mempercepat pertumbuhan tanaman (tinggi, jumlah anakan, cabang dan lain-lain) dan menambah kandungan protein tanaman.

Kelompok memberikan pengaruh yang berbeda nyata $(\mathrm{P}>$ 0,05). Hal ini dapat dijelaskan bahwa kandungan unsur hara tanah bervariasi untuk setiap kelompok. Ketersediaan hara dalam tanah dalam penelitian ini diketahui melalui pengujian laboratorium. Pada awal penanaman kadar unsur haranya relatif sama antar kelompok. Rataan kandungan unsur hara tanah sesudah panen dapat dilihat pada Tabel 3.

Tabel 3. Rataan Unsur HaraTanah sesudah Panen

\begin{tabular}{llllc}
\hline \multirow{2}{*}{ Unsur Hara Makro } & \multicolumn{5}{c}{ Perlakuan } \\
\cline { 2 - 5 } & $\mathbf{T}_{\mathbf{0}}$ & $\mathbf{T}_{\mathbf{1}}$ & $\mathbf{T}_{\mathbf{2}}$ & $\mathbf{T}_{\mathbf{3}}$ \\
\hline $\mathrm{N}(\%)$ & 0,0353 & 0,0350 & 0,0415 & 0,0438 \\
$\mathrm{P}(\mathrm{ppm})$ & 5,74 & 6,33 & 7,27 & 8,83 \\
$\mathrm{~K}(\mathrm{ppm})$ & 2,46 & 3,25 & 3,38 & 3,644 \\
\hline Sumber $:$ Hasil Analisa Tanah di Laboratorium FAPERTA & UNSRAT, Manado (2009).
\end{tabular}

Jelas terlihat adanya perbedaan antara unsur hara tanah sebelum dan sesudah penanaman jagung. Unsur hara $\mathrm{N}$ pada perlakuan menggunakan pupuk kompos, sedangkan terendah pada perlakuan menggunakan pupuk inorganik. Sidik ragam menunjukkan tidak adanya perbedaan kandungan unsur hara $\mathrm{N}$ antara tanah yang di pupuk dibanding dengan tanpa pemupukan. Kandungan unsur hara tanah setelah selesai panen lebih rendah dibanding pada awal penanaman. Hal ini terlihat jelas bahwa tanaman jagung memanfaatkan
$\mathrm{N}$ tanah untuk pertumbuhan maupun produksinya.

\section{Pengaruh Perlakuan terhadap Panjang Tongkol dan Lingkar Tongkol Panjang Tongkol}

Berdasarkan Tabel 2, dapat dilihat bahwa rata-rata panjang tongkol pada percobaan ini bervariasi yaitu $13,15 \mathrm{~cm}( \pm 1,85)$ sampai 15,76 $\mathrm{cm}( \pm 0,62)$. Untuk rataan tertinggi pada perlakuan $T_{3}$ dan terendah perlakuan $\mathrm{T}_{2}$. Hasil analisis keragaman menunjukkan bahwa perlakuan memberikan pengaruh yang 
berbeda nyata $(\mathrm{P}>0,05)$ terhadap panjang tongkol. Dari hasil uji Beda Nyata Jujur (Lampiran 2b) terlihat adanya perbedaan nyata antara Perlakuan $T_{3}$ dengan perlakuan $T_{0}, T_{1}$ dan $T_{2}$, namun perlakuan antara $T_{0}, T_{1}$ dan $T_{2}$ tidak berbeda nyata.Hal ini dipengaruhi oleh karena pada perlakuan $\mathrm{T}_{3}$ menggabungkan antara pemupukan anorganik dan organik sedangkan pada $T_{0}$ hanya sebagai kontrol perlakuan.

\section{Lingkar Tongkol}

Berdasarkan Tabel 2, rata-rata lingkar tongkol pada percobaan ini bervariasi yaitu $14,06 \mathrm{~cm}( \pm 1,16)$ sampai $15,62 \mathrm{~cm}( \pm 0,81)$. Rataan tertinggi ada pada perlakuan $\mathrm{T}_{3}$ dan terendah pada perlakuan $T_{1}$. Hasil analisis keragaman (Lampiran 3a) menunjukkan bahwa perlakuan memberikan pengaruh yang berbeda nyata $(\mathrm{P}>0,05)$ terhadap lingkar tongkol. Dari hasil Uji Beda Nyata Jujur perlakuan $T_{3}$ berbeda nyata dengan perlakuan $T_{0}$ dan $T_{1}$.

Usaha untuk dapat meningkatkan produktifitas suatu tanaman diantaranya dapat dilakukan dengan pemberian pupuk, baik pupuk organik maupun pupuk anorganik. Pemberian pupuk organik dapat memperbaiki sifat-sifat tanah seperti sifat fisik, kimia dan biologi tanah. Bahan organik merupakan perekat butiran lepas, sumber hara tanaman dan sumber energi dari sebagian besar organisme tanah (Hakim et al., 1986). Pemberian pupuk organik dapat meningkatkan daya larut unsur $\mathrm{P}, \mathrm{K}, \mathrm{Ca}$ dan $\mathrm{Mg}$, meningkatkan C-organik, kapasitas tukar kation, daya serap air, menurunkan kejenuhan $\mathrm{Al}$ dan bulk density (BD) tanah (Aribawa, 2008).
Selain pemberian pupuk organik, pemberian pupuk anorganik sebagai sumber hara $\mathrm{N}$ merupakan usaha yang banyak dilakukan dalam meningkatkan produktifitas tanaman khususnya jagung. Pupuk urea sebagai sumber hara $\mathrm{N}$ dapat memperbaiki pertumbuhan vegetatif tanaman, dimana tanaman yang tumbuh pada tanah yang cukup N, berwarna lebih hijau (Hardjowigeno, 1987).

\section{Pengaruh Perlakuan terhadap Bobot Pipilan Kering Jemur}

Pada Tabel 4, dapat dilihat rataan bobot pipilan kering pada percobaan ini berkisar antara 1.288,32 kg.petak ${ }^{-1}( \pm 201,28)$ sampai 2.372,37 kg.petak ${ }^{-1}( \pm 86,41)$, dimana berat pipilan kering jagung terus meningkat. Hasil analisis Keragaman (Lampiran 4a) menunjukkan bahwa perlakuan memberikan pengaruh yang berbeda sangat nyata $(\mathrm{P}>0,01)$ terhadap bobot pipilan kering. Hasil uji Beda Nyata Jujur menunjukkan bahwa perlakuan yang menggabungkan antara pupuk anorganik dan organik perlakuan $\mathrm{T}_{3}$ memiliki bobot pipilan kering yang berbeda nyata lebih tinggi dibandingkan dengan semua perlakuan antara $\mathrm{T}_{0}, \mathrm{~T}_{1}$ dan $\mathrm{T}_{2}$.

\section{KESIMPULAN}

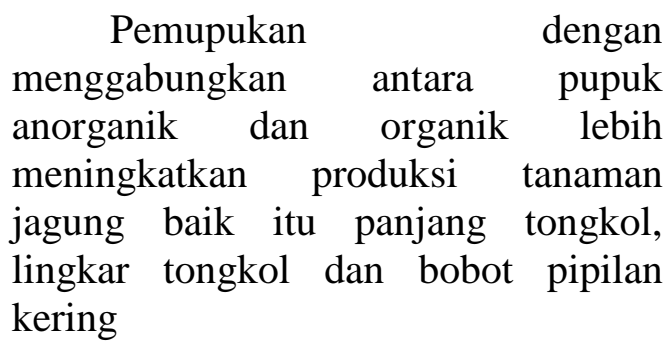




\section{DAFTAR PUSTAKA}

Adisarwanto, T., Y. E. Widyastuti. 2008. Meningkatkan Produksi Jagung di Lahan Kering, Sawah dan Pasang Surut. Penebar Swadaya. Jakarta.

Anonim. 2003. Pedoman Pelaksanaan Pertemuan

Masyarakat Agribisnis Jagung. Direktorat Serealia. Jakarta.

Aribawa, I. B. 2008. Pengaruh Beberapa Jenis Pupuk Organik dan Pupuk Urea Terhadap Sifat Tanah dan Hasil Kacang Panjang di Lahan Kering Pinggiran Perkotaan Denpasar Bali. Pengkajian Teknologi Pertanian Bali. www.deptan.go.id [31 Maret 2009).

Dinas Peternakan Provinsi Sumbar. 2008. Potensi Pupuk Organik. http://www.disnaksumbar.org [30 November 2008).

Halliday, D. J. and M. E. Trenkel. 1992. IFA World Fertilizer Use Manual. International Fertilizer Industry Association, Paris.

Laboratorium Faperta. 2009. Hasil Uji Kandungan Hara Tanah di Laboratorium Faperta. Universitas Sam Ratulangi Manado.

Nyanjang, R., A. A. Salim., Y. Rahmiati. 2003. Penggunaan Pupuk Majemuk NPK 25-7-7 Terhadap Peningkatan Produksi Mutu Pada Tanaman The Menghasilkan di Tanah Andisols. PT. Perkebunan Nusantara XII. Prosiding Teh
Nasional. Gambung. Hal 181185. 